Miftabul Huda

\title{
ASSESSING THE RELATION BETWEEN MAJORITY AND MINORITY GROUPS A Critical Study on the Spirit of Domination in a Heterogeneous Society
}

\author{
UIN Maulana Malik Ibrahim Malang \\ Email: mr mifta@yahoo.co.id
}

\begin{abstract}
Group relation within any heterogeneous society in which people with their different characteristics and identities live together tends to run unequally due to the majorities' domination toward minorities. Their spirit of domination is philosophically based on Charles Darwin's theory of evolution "The Survival of the Fittest" which later incarnates itself in social domain and is used to justify that their domination upon minority groups is a kind of natural selection process. When this idea is perceived continuously from generation to generation, minorities will be the everlasting disadvantaged victims of the other group's domination and suffer persistent annibilation and oppression, extending from the most moderate form like prejudice to the most extreme one such as discrimination. Besides being intended to discuss the complicated relation between majority and minority groups and explore the significance of the spirit of domination in determining the dynamics of group relation, this study is also aimed at offering some alternative ways to create egalitarian atmosphere in a beterogeneous society. Indeed, such new future is not impossible to be reached as far as reconciliation process is consistently carried out by both groups. Reconciliation, which might involve assimilation, accommodation, amalgamation, and pluralism, is the main key to realize equal and mutual relation between majority and minority groups.
\end{abstract}

Keywords: Group Relation, Majorities, Minorities, Domination, Heterogeneous Society. 
Abstrak: Hubungan sosial dalam masyarakat beterogen yang di dalamnya mereka yang berbeda karakter dan identitas bidup bersama cenderung berperilaku kurang bijak disebabkan adanya dominasi atas kelompok minoritas. Dominasi di sini secara filosofis didasarkan pada teori evolusi Charles Darwin tentang "The Survival of Fittest" yang menginkarnasi dirinya dalam dominasi sosial dan digunakan untuk menjustifikasi bahwa dominasi mereka atas kelompok minoritas adalah proses alam. Ketika gagasan ini terus dipertahankan dari generasi ke generasi, kelompok minoritas akan menjadi golongan yang paling dirugikan dan akan merasakan tekanan yang luar biasa, mulai dari yang paling 'wajar' seperti prasangka hingga yang paling 'ekstrem' seperti diskriminasi. Selainmendiskusikan relasi kompleks antara kelompok mayoritas dan minoritas, sekaligus mengeksplorasi bagaimana dominasi muncul dalam relasi antarmasyarakat yang heterogen ini, studi ini juga berusaha menawarkan cara alternatif untuk menciptakan iklim yang egalitarian dalam masyarakat tersebut. Bahkan, masa depan yang baru ini tidak mustahil dicapai sejauh proses rekonsilitasi terus dilakukan oleh kedua kelompok itu. Rekonsiliasi, yang sekaligus juga melibatkan asimilasi, akomodiasi, amalgamasi, dan pluralisme, merupakan kunci utama menciptakan relasi yang setara antara kelompok mayoritas dan minoritas.

Kata kunci: relasi kelompok, mayoritas, minoritas, domiasi, masyarakat beterogen

\section{Prologue}

Humankind contains people with different skin colors, languages, religions, cultures, and customs. These traits later become the source for the distinction, or stratification, of human being. On behalf of simplifying the broad and various types of human beings, they are, then, classified and included to a certain group whose members share similar characteristics. Although this division has proven to give valuable contribution to the increase of social studies, some problems appear due to the horizontal conflicts between or among those classified groups. The most obvious and frequent one which commonly occur in almost any heterogeneous country is a clash of interest between majority and minority group(s). ${ }^{1}$

${ }^{1}$ The terms majority and minority does not entirely refer to statistical number. Rather, both are used to characterize the possession of power in determining public policy. 
Throughout history and in all societies, people have been intensely conscious of such relation as the most complicated social issue which might cause an endless conflict between the mainstreamgroup and the other. ${ }^{2}$ Discussions of inter-group relation have long been a central concern of sociologists since, in some cases, it is prone to bring a sociological "unpleasant" impact upon the minorities. This problem is faced by even the fully democratic nation. What has been experienced by black minorities in the United States of America can be the most representative example here ${ }^{3}$.

In the developed country which declares itself as the homeland of democracy, prejudice and discrimination against minority groups had been, are being, and probably will continuously be applied. The inconsistencies between American democratic ideal which guarantees absolute equality among diverse groups and racial practice, which is inconsistent with democratic ideology and functions as a spearhead of anti-democratic forces in organized capitalistic society, became increasingly apparent in the country. ${ }^{4}$

The symbol of the Statue of Liberty welcoming the poor and the huddled masses has often masked difficulties experienced by members of minorities in America. The fact of American Paradox

The concept of majority and minority will be further discussed in the later part of this writing.

${ }^{2}$ See in Barry J. Wishart and Louis C. Reichman, Modern Sociological Issues (New York: Macmillan Publishing Co., 1979), 356-357.

${ }^{3}$ Of many social problems, the racial conflict between American Blacks and Whites is considered the most persistent. From the beginning of the civil war until today American blacks, as minority group, experienced the greatest discrimination and segregation ever. Although Congress had passed the landmark Civil Rights Act in 1964 which prohibited racism in virtually all areas of social life, full equality is still far from achieved. Horton presents the fact that Black households are still worth about 10 percent of white households. Black unemployment remained more than twice as high as white unemployment throughout the 1980s. Blacks seeking services in hotels and restaurants were still met by a bland refusal of proprietors to obey the law, or else by evasion, inattention, and humiliation. As members of minority group, American Blacks still lag behind whites in almost any aspects of life. See in Paul B. Horton, The Sociology of Social Problems (New Jersey: Prentince Hall-Englewood Cliffs, 1991), 321.

${ }^{4}$ Rudolf Siebert, "The Phenomenon of Racism" in Concilium Journal, ed. 151, (1982), 6 . 
has been well-identified by Myrdal. He argues that what he used to call The American Dilemma, i.e. the discrepancy between the ideal of democracy and the reality of unequal relation between majorities and minorities, still exists nowadays, though to a less degree than in the past. ${ }^{5}$

The fact of inequality occurred in the United States might also happen in any heterogeneous country which has multi ethnic, religious, racial, and cultural groups. This diversity, to some extent, has been the cause of a variety of conflicts between the majorities (the "superior" group) and the minorities (the "inferior" group). Many experts suggest that the majorities' spirit of domination becomes the most persistent cause of their unequal treatment toward the minorities. ${ }^{6}$

The above description has resulted one assumption that the origin of majority-minority group relation and its extinction are too far complex to be circumscribed by simplistic view. The spirit of domination seems to be natural consciousness, which is actually false, of a majority group concerning itself and the minorities. It is not merely sociological concern with human communal characteristics, their differences, interrelationships, and conflicts, but a very emotional and passionate ideology.

This study is aimed at discussing the relation between majority and minority groups in a heterogeneous nation, exploring the presence of the spirit of domination as the major cause of majorities' annihilation toward minorities, and offering the possibly applied ways to build mutual understanding between both groups.

\section{Reviewing the Concept of Majority-Minority Relation}

In a relatively heterogeneous society, minority groups, or simply minorities, are defined in contrast to the dominant ones or majorities. The choice of terms is unfortunate because they have numerical connotations. Despite their literal meaning, minorities

\footnotetext{
${ }^{5}$ Wide explanation related to the paradoxical condition of the USA can be found in G. Myrdal, An American Dilemma (New York: Harper \& Row, 1971).

${ }^{6}$ Beth B. Hess, Sociology (New York: Macmillan Publishing Co., 1985), 223; Richard F. Larson, et.al., Introductory Sociology: Order and Change in Society (Dubuque: Kendall/Hunt Publishing Inc., 1989), 336-337.
} 
and majorities are not statistical categories but social status. "Majority" refers to the possession of power to control over central sectors of social life; politic, culture, economic, law, including the standards of beauty and worth. In contrast, a minority group should be understood as a socially self-conscious population, with hereditary membership and a high degree of in-group marriage, who suffers disadvantage at the hands of a dominant segment of a country. ${ }^{7}$

The example of majority-minority group can be seen in the following cases. In term of Indonesian economic sector, the descents of Chinese ancestries (the ethnic of Tionghoa) are considered majorities since they play very significant role in determining the dynamics of the economic stability of the country although they constitute not more than 8 percents of the Indonesian citizens. While Iraq was led by Saddam Hussein, Sunni became the majority group. However, in its neighboring country led by Ayatollah Khomeini, Iran, Sunni becomes the minority group, and Syi'ah does the majorities.

Blacks, for instance, are considered a minority in South Africa even though they make up 68 percent of the population, because they are the subordinate group. Similarly, the whites in South Africa are called the majority group because they become the only policy holder and decision maker in the country although they make only 18 percent of the population. Another example, in the United States, Americans of English descents are today only 22 percent of the population, but because of their continuing social and cultural influence, they are still considered the dominant group. ${ }^{8}$

A sociologist Vander Zanden distinguishes five properties as characteristics of minority groups: ${ }^{9}$

${ }^{7}$ The above definition is proposed by James W. Vander Zanden, The social Experience (New York: McGraw Hill Publishing Inc, 1990b), 301; Beth B. Hess, Sociology, 223-224.

${ }^{8}$ Alex Thio, Sociology; a Brief introduction (New York: HarperCollins Publisher, 1991), 171.

9 James W. Vander Zanden, Sociology; the Core (New York: McGraw Hill Publishing Inc., 1990a), 188. 
1. A minority is a social group whose members experience discrimination, oppression, or persecution at the hands of another social one, the majority group. As a result of power differences between the two groups, the members of a minority are disadvantaged. Equally important, they are the source of the other group's advantages since the oppression of one people confers privilege and status on another.

2. A minority is characterized by physical or cultural traits that distinguish it from the majorities. Thus, its members are lumped together and "placed" in less desirable positions in the social structure.

3. A minority is a self-conscious social group characterized by a consciousness of oneness. Its members possess a social and psychological affinity with others like themselves, providing a sense of peoplehood. This consciousness of oneness is accentuated by the members' common suffering and burdens.

4. Membership in a minority group is generally not voluntary. It is an ascribed position, since an individual is commonly born into status. Thus a person does not usually choose to be Moslem or Christian, Madurese or Javanese, black or white, and so on.

5. The members of a minority, by choice or necessity, typically marry within their own group (endogamy). The majority group strongly discourages its members from marrying members of the minority group, and usually scorns those who do. The minority may encourage its members among themselves to preserve their unique cultural heritage.

The above characteristics of minority groups cause them to be treated unequally toward the majorities. By virtue of the power differences between the two groups, the members of a minority are frequently disadvantaged. The reality of unequal power combined with prejudices enables some groups of people to treat others unequally by denying them the access of opportunities, resources, and decision-making processes. Majorities and minorities are finally involved in 'unfair' group relation.

The Spirit of Domination; the Manifestation of Darwinism in Inter-Group Relation

What is the philosophical motive of any majority group's domination upon minorities? The cause of such attitude can be 
actually traced to a natural selection theory which proposes that only the strongest, the most superior, and the fittest group might exist. This idea, which is originated from Darwin's evolution theory, roots deeply on the ideology of -what is commonly called-Social Darwinism which scientifically "guarantees" the majorities to continue their dominance over the minorities.

Hofstadter explains that Social Darwinism was a late $19^{\text {th }}$ century sociological theory that was based on the theories of biological evolution and natural selection, survival of the fittest, put forth by biologists Charles Darwin and Alfred Russel Wallace. Darwin's theory of evolution, which holds that species are engaged in a struggle for existence in which only the fittest will survive, suggests that different social groups were at different stage of evolution; the more advanced groups were destined to dominate groups less "fit." "This idea, then, provided justification for domination, oppression, exploitation, and colonialism.

Social Darwinism, then, becomes the most fundamental reason for the scientific legacy of a majority group's domination upon the minority one. Scientific legacy of the majorities' domination over minorities endowed the scientific aura through the concept of natural selection. ${ }^{11}$ For the social Darwinists, the most superior group, i.e. the majorities, is entitled to the greatest living space, even if the living space of others has to be violated. Through this perspective, a domination of the majority group upon the minorities is no longer viewed as mythical but scientific.

The spirit of domination has been beautifully masked with the rationalization of the irrational-structure in which one group is considered natural to exploit and sometimes even annihilate others. $^{12}$ To maintain the domination, the majorities try

${ }^{10}$ According to Social Darwinists whose idea is originally based on the biological theory of natural selection, Societies, like organisms, evolved by a natural process through which the fittest numbers (in this case is the majority group) survived or were most successful. Social Darwinism was also used to support imperialism - peoples who viewed themselves as culturally superior, being allegedly more fit to rule those whom they deemed less advanced. See in Richard Hofstadter, Social Darwinism in American Thought (New York: Braziller Co., 1965).

\footnotetext{
${ }^{11}$ Encyclopedia of Knowledge (Connecticut: Grolier Incorporated, 1993), 149.

${ }^{12}$ Rudolf Siebert, “The Phenomenon of Racism”, 6.
} 
systematically to reject the existence of the minorities by pushing them apart from accesses to all aspects of life. In short, there is always a great tendency that minorities are alienated, annihilated, and discriminated, then become the persistent victims of majority group's domination.

\section{Majority Group Domination; the Idea of Manifest Destiny?}

One of the most fundamental issues of group relations is the effect of contact. Some writers maintain that increased contact between different groups will lead only to heightened conflict; others hold that increased contact between such groups will decrease prejudice and discrimination. However, social science evidence supports neither extreme. Increased interaction, whether of individual or groups, intensifies and magnifies the processes already underway. ${ }^{13}$ Above all, in most cases, the acceptance upon minority groups is not necessarily total and unconditional since the most common group-relation runs unequally, i.e. inhumane oppression, extending from the most moderate form such as prejudice to the most radical one like discrimination, of the majorities toward the minorities for the sake of domination.

Prejudice, the 'softest' form of majority group's rejection upon minorities, is so prevalent in contemporary life that sociologists usually assume it as "part of human nature." The English term "prejudice" and its equivalents in many other European languages (French prejudge; German Vorurteil; Portuguese preconceito) literally means a prejudgment. It refers primarily to a prejudgment or a preconception reached before the relevant information has been collected or examined and therefore based on inadequate or even imaginary evidence. ${ }^{14}$

Gordon Allport defines prejudice as "an antipathy based upon a faulty and inflexible generalization"15. Thus, prejudice, according to Allport, covers attitudes of aversion and hostility toward the

${ }^{13}$ International Encyclopedia of the Social Sciences (New York: The MacMillan Company \& The Free Press, 1968), 269.

${ }^{14}$ Ibid., 439.

${ }^{15}$ Gordon Allport, The Nature of Prejudice (Cambridge, Mass: Addison Wesley, 1975), 22. 
members of a minority group simply because they belong to it and so are presumed to have the objectionable qualities that are ascribed to it.

Sociologist Herbert Blumer, as quoted by Vander Zanden, notes that four feelings typically characterize dominant group members' prejudice:

1. A sense that they are superior to members of the minority group.

2. A feeling that minority members are by their nature different and alien.

3. A sense that dominant-group members have a proprietary claim on privilege, power, and prestige.

4. A fear and suspicion that members of the minority have designs on dominant group benefits. ${ }^{16}$

The above characteristics imply on a conclusive idea that prejudice is so complex that it may employs respectively cognitive the ideas or opinions the majorities have about minority groups who become the objects of such prejudgment-, affective - the feeling, either favorable or unfavorable, about the minorities- and conative dimensions - or behavioral, the oriented and prescribed actions reflecting majority group's acceptance or rejection upon minorities-

It is, however, hard to evaluate the causes of prejudices since, according to Hofstätter, it is a "normal" phenomenon of human social life and that no one is free from this attitude. However, this appears to be an extreme and over-simplistic unjustified conclusion. Thus, although the cause of prejudice is difficult to be exactly identified, its origin is still eligible and relevant to be evaluated here.

One of the most significant factors associated with the use of prejudice is rationalization, which in this context is characterized by the tendency to justify and rationalize any relatively irrational attitude. This is usually mentioned in connection with the minority group's burden and similar formulation: they, whom we persecute because of their ideas, can be saved only if they accept the true (that is to say, our) concept; they, to whom we do nothing, are planning to destroy $u s$, and we are simply exercising the right to protect

\footnotetext{
${ }^{16}$ James W. Vander Zanden, Sociology; the Core, 276.
} 
ourselves. ${ }^{17}$ These arguments, when presented by any majority groups in all sincerity, which is so often in the past and not so rarely in the present, have given the conviction that what they are doing is somehow noble.

Whatever the form of prejudice, the impact of the attitude is so clear. It enables the dominant group to maintain the minorities in a state of subservience, to exploit them, to reduce their power to compete on equal positions, and to keep them "in their place." If the above phenomena continue repeatedly in the future, the equality of different groups will have never been successfully reached.

Another form of majority group's rejection, which is so extreme, on the minorities is discrimination. The term sociologically means perceiving distinctions among phenomena or to be selective in one's judgment. The broadcast sociological ideas of discrimination assume that members of minority groups have no inherent characteristics warranting inferior social outcomes. ${ }^{18}$ Thus, discrimination is not merely an isolated individual acts but "a system of social relations" that produce intergroup inequities in social outcomes.

Discrimination covers behavior and action to exclude the members of minority group from access to certain facilities and activities such as education, employment, housing, and so forth. Thus, group discrimination is a treatment which involves the arbitrary denial of privilege, prestige, and power, given to members of minority whose qualifications are equal to those of members of the dominant group. ${ }^{19}$

Discrimination reflects the persistent application criteria that are arbitrary, irrelevant, or unfair by dominant standards, with the result that majorities receive an undue advantage and minorities, although equally qualified, suffer an unjustified penalty. When

${ }^{17}$ Hooton describes such kind of rationalization through his tendentious phrase that they (the dominant group), "can rape in righteousness and murder in magnanimity." Ernest A. Hooton, Apes, Men, and Morons (New York: Putnam, 1968), 151.

18 Aaron Antonovsky, "The Social Meaning of Discrimination" in Phylon, ed.21 (1970), 81.

19 R. M. Williams, The reduction of Intergroup Tensions (New York: Social Science Research Council, 1976), 39. 
comparing those who are advantaged with those who are disadvantaged, one can speak of discrimination as the unequal treatment of equals. When only those who are being discriminated against are considered, it is also useful to reverse this phrase and to speak of the equal treatment of unequals, i.e. the members of minority groups are treated alike despite variation in their competence, training, or other personal characteristics. ${ }^{20}$

Based on the above description, people would think that the impact of majority group's spirit of domination which is manifested via, for instance, prejudice and discrimination are variously revealed in a pattern of objective disadvantageous life conditions. Minorities are alienated, annihilated, isolated from using the facilities of the majorities, and less likely to participate in the activities of the mainstream group.

On the subjective side, it is difficult to overestimate the effects of unfair group relation on personality of belonging to a group which is generally regarded inferior and so treated. Self-hatred, which has occasionally been applied to the reaction of members of minorities who attempt in one form or another to reject their own identity, is probably the most worth-noting impacts faced by members of minority group. ${ }^{21}$

Up to this critical point, domination seems to be the Manifest destiny addressed to the majorities. However, the other group has never requested to be created as minorities. If only they could freely choose, they would happy-heartedly be the dominants. Is there still a little path to realize an egalitarian heterogeneous society in which all members of any group can enjoy equality?

\section{Searching for Equality in Heterogeneous Society}

In response to the previously mentioned case, there have been strong movements in almost any democratic country to combat inequality and eradicate it from the nation. Progress toward equality is starting, but road ahead is much more difficult than anyone had 498-500.

${ }^{20}$ Encyclopedia of Sociology (New York: MacMillan Publishing Company, 1992),

${ }^{21}$ A scientific research on how members of a minority group feel "Self-Hatred" has ever been conducted by Kauffmann. The result of his study is discussed in Harry Kaufmann, Social Psychology; the Study of Human Interaction (New York: Holt, Rinehart and Winston Inc, 1973), 186-187. 
suspected a few years back. Much has been accomplished, many barriers have been destroyed, new understanding has been introduced, new structures are beginning to emerge, but much more still needs to be accomplished. In fact, the more people are able to accomplish, the more people realize how much more still needs to be done. People can only hope that majorities and minorities are able to produce a new future; a new post-dominant, post-modern, post-group reconciled society of freedom, equity, and peace.

Such new enlightened future is not impossible to be realized in any heterogeneous nation through reconciliation of the majority and minority groups. This would be the step from the unfair society, which drives the dominated and the dominant group into illness, to a humane society. No members of minority group, the victim of majorities' domination, who knows how to appease this false projection in him/herself is similar to the disaster which overtakes him or her as all persecuted animals and men on this globe. Reconciliation, not hate, must be the last word of the history of group domination. The reconciliation process might take one of the following possible ways:

\section{Assimilation}

One way that a dominant group seeks to "solve" a minority group "problem" is to eliminate the minority by absorbing it through assimilation. According to a widely quoted point of view, assimilation is a process of interpenetration and fusion in which persons or groups acquire the memories, sentiments, and attitudes, of other groups, and, by sharing their experience and history, incorporated with them in a common cultural $\operatorname{life}^{22}$. Assimilation covers the process whereby groups with distinctive identities become culturally and socially fused so that a minority group can accept the idea of the dominant group, fading into the mainstream society.

Assimilation simply refers to a type of cultural adaptation in which an individual gives up his or her own cultural heritage and

\footnotetext{
${ }^{22}$ Robert E. Park and Ernest W. Burgess, Introduction to the Science of Sociology (Chicago: Univ. of Chicago Press, 1967), 735.
} 
adopt the dominant cultural identity. ${ }^{23}$ As a result of assimilation, group's boundaries become more penetrable and permeable. Thio further says that, taken as a whole, assimilation can be expressed as $\mathrm{A}+\mathrm{B}+\mathrm{C}=\mathrm{A}$ where minorities $(\mathrm{B}$ and $\mathrm{C})$ lose their sub-cultural traits and become indistinguishable from the majority group $(\mathrm{A}){ }^{24}$

\section{Accommodation}

Unlike assimilation which employs fusion, accommodation refers to a process of compromising characterized by toleration. For the sake of toleration, the accommodation pattern often includes avoidance, an effort by the minority to minimize contacts with the majority. ${ }^{25}$ The clannishness of a minority is a kind of avoidance technique usually occurred in a heterogeneous society.

Horton explains the accommodation process by giving an example of the relation between black and white Americans. ${ }^{26}$ Some blacks resented white domination but made expedient compromises with it to advance themselves. Fearful of attacking whites' prejudices, they sought to manipulate these prejudices to their own advantage. It involved observing racial etiquette and making no challenges to the racial status quo.

\section{Amalgamation}

Like assimilation, amalgamation requires groups to give up their distinct identities. But unlike assimilation, amalgamation demands respect for the original subcultures. In amalgamation, various groups are expected to contribute their own identities to the development of new ones, without pushing anything at the expense of another. Usually, this blending of diverse groups results from intermarriage. It can be described as $\mathrm{A}+\mathrm{B}+\mathrm{C}=\mathrm{D}$, where $\mathrm{A}, \mathrm{B}$, and $\mathrm{C}$ represent different groups jointly producing a new identity (D) unlike any of its original components. ${ }^{27}$

Considering the definition that amalgamation covers the creation of "new" culture derived from different subcultures, the

${ }^{23}$ Judith N. Martin, et.al., Intercultural Communication in Contexts (California: Mayfield Publishing Co., 2000), 337.

${ }^{24}$ Alex Thio, Sociology; a Brief introduction, 177.

${ }^{25}$ International Encyclopedia of the Social Sciences, 438.

${ }^{26}$ Paul B. Horton, The Sociology, 310.

27 Alex Thio, Sociology; a Brief Introduction, 177. 
concept can be said similar to acculturation in which groups of individuals having different characteristics come into continuous first hand contact, with subsequent changes in the original patterns of either or both groups. ${ }^{28}$ In sum, both amalgamation and acculturation idealize an appreciation for the equal worth of various groups.

\section{Pluralism}

Some minority groups do not wish to be assimilated, accommodated, nor amalgamated. They value their separate identities, and they prefer pluralism, a situation in which diverse groups coexist side by side and mutually accommodate themselves to their differences. Pluralism requires greater mutual respect for other groups' tradition. Unlike either assimilation or amalgamation, pluralism encourages each group to take pride in its distinctiveness, to be conscious of its heritage, and to retain its identity. Such pluralism can be simply shown as $\mathrm{A}+\mathrm{B}+\mathrm{C}=\mathrm{A}+\mathrm{B}+\mathrm{C}$, where various groups continue to keep their identities while living together in the same society. $^{29}$

The above concepts of group reconciliation, however, are not one-sided way. The effort to reach group equality needs seriousness of both majorities and minorities. Two elements are needed together to realize an egalitarian community: the majority group's willingness to stop dominating and taking benefit from the inferiority of the minorities and the minority group's struggle to eliminate majority domination. Without both, the prospect is bleak indeed.

\section{Epilogue}

Herrnstein and Murray state in Harris' Theories of Culture in Postmodern Times that all basic problems of human beings arise from having too much equality in their lives. They argue that people

28 The similarities between the concept of amalgamation and that of acculturation have been briefly elaborated in Robert Redfield, et.al. American Anthropologist. (Manhattan: RB Inc., 1970), 149.

${ }^{29}$ James W. Vander Zanden, Sociology; the Core, 191. 
need to learn to live with more inequality to reduce the problems. "It is time ... once again to try living with inequality...," they said. ${ }^{30}$

As noted in this study, however, the above statement is proven irrelevant with the social condition within heterogeneous countries since "too much inequality has given birth to majority group's domination upon minorities" and "majority group's spirit of domination has increased the unequal treatment toward minorities." People need not to try living with inequality. Rather, any majority groups with various characteristics and values must learn to respect other people (this is to say minorities) and live with them equally.

For a heterogeneous society, to continue their march to gain equality requires two respective conditions: the majorities' willingness to accept, promote, and tolerate the other group's special characteristics, and the minorities' determination to take full advantage of every opportunity. Both the majority group's willingness to leave out their old-fashioned dominant idea and the minorities' self-motivation to break the blind domination of the other group are needed to eliminate inequality.

${ }^{30}$ See in Marvin Harris, Theories of Culture in Postmodern Times (Walnut Creek USA: Alta Mira Press, 1999), 75. 


\section{Bibliography}

Allport, G. (1975). The Nature of Prejudice. Cambridge, Mass: Addison Wesley.

Antonovsky, A. (1970). "The Social Meaning of Discrimination," dalam Phylon vol. 21.

Harris, M. (1999). Theories of Culture in Postmodern Times. Walnut Creek USA: Alta Mira Press.

Hess, B.B. (1985). Sociology. New York: Macmillan Publishing Co.

Hofstadter, R. (1965). Social Darwinism in American Thought. New York: Braziller Co.

Hooton, E. A. (1968). Apes, Men, and Morons. New York: Putnam.

Horton, P. B. (1991). The Sociology of Social Problems. New Jersey: Prentince Hall-Englewood Cliffs.

Kaufmann, H. (1973). Social Psychology: The Study of Human Interaction. New York: Holt, Rinehart and Winston Inc.

Larson, R. F., dkk. (1989). Introductory Sociology: Order and Change in Society. Dubuque: Kendall/Hunt Publishing Inc.

Martin, J. N., dkk. (2000). Intercultural Communication in Contexts. California: Mayfield Publishing Co.

Myrdal, G. (1971). An American Dilemma. New York: Harper \& Row.

Park, R. E., dan Burgess, E. W. (1967). Introduction to the Science of Sociology. Chicago: Univ. of Chicago Press.

Redfield, R., dkk. (1970). American Anthropologist. Manhattan: RB Inc.

Siebert, R. (1982). “The Phenomenon of Racism”, dalam Concilium Journal vol. 151.

Thio, A. (1991). Sociology; a Brief introduction. New York: Harper Collins Publisher.

Vander, Z., dan James W. (1990). Sociology; the Core. New York: McGraw Hill Publishing Inc.

Vander, Z., \& James, W. (1990). The social Experience. New York: McGraw Hill Publishing Inc.

Williams, R. M. (1970). The reduction of Intergroup Tensions. New York: Social Science Research Council.

Wishart, B., J., \& Reichman, L. C. (1970). Modern Sociological Issues New York: Macmillan Publishing Co. 
- (1993). Encyclopedia of Knowledge. Connecticut: Grolier Incorporated.

. (1992). Encyclopedia of Sociology. New York: MacMillan Publishing Company.

(1968). International Encyclopedia of the Social Sciences. New York: The MacMillan Company \& The Free Press. 